\title{
Zamek w Lańcucie - ogniwo systemu obrony południowo-wschodnich granic Polski w XVI i XVII wieku
}

I. Lańcut a strategia obrony $w$ jego regionie. Zamek w Łańcucie, będący od lat jedną z bardziej znanych atrakcji turystycznych w Polsce, leży na ruchliwym ongiś handlowym szlaku, wiodącym z Krakowa na Ruś. Łańcut zapisał się na kartach historii nie tylko jako rodowa rezydencja arystokratyczna, ale też jako jedno z ogniw systemu obrony dawnej Rzeczypospolitej. Spełniał rolę warowni gotowej do podjęcia funkcji defensywnych w krytycznym dla regionu momencie. Współcześnie znany jest przede wszystkim jako dawna magnacka siedziba, pełniąca funkcje muzealne. Zaznaczona na wstępie obronna cecha Łańcuta uwzględniała oprócz zamku również miasto i kościół. Jednakże w niniejszej pracy przedstawione zostaną przede wszystkim losy łańcuckiego założenia rezydencjonalno-obronnego.

Szeroko pojęta sztuka obronna przeważnie ściśle związana jest z miejscem do jej tworzenia i strategią militarną stron potencjalnego konfliktu. $\mathrm{Na}$ przedmiotowym obiekcie zaważyły dwa zasadnicze obszary wojenne. Jeden w osi rzeki Dniestr, zwany wołoskim, drugi w osi Bohu. Kończy go wierzchowina na skraju Podola i przedpolu Lwowa. Naturalne bramy wiodące stąd na Kraków i Warszawę prowadzą w głąb kraju w trzech kierunkach. Kierunek północno-zachodni, na Sandomierz, w paśmie dolnego biegu Sanu, przez Lubaczów i Leżajsk. Drugi kierunek, południowo-zachodni, też biegnący doliną Sanu, oraz trzeci - wprost na zachód, doliną Wisłoki, przez Jarosław, Przeworsk, Łańcut, Tarnów do Krakowa ${ }^{1}$.

Wymienione miejscowości trzeciego szlaku (Jarosław, Przeworsk, Łańcut, Tarnów), były głównymi ogniwami łańcucha obronnego południowej Polski w XVI w. Wzmocniony został od południa przez rygle doliny Sanu, począwszy od Przemyśla, przez Krasiczyn, Babice, Dubiecko po Dynów. Od północy zaś przejście było zamknięte przez Lubaczów, Leżajsk, Tarnogród, co

${ }^{1}$ J. Bogdanowski, Fortyfikacje tańcuckie na tle matopolskiej sztuki obronnej, Łańcut 1976, s. 65 . 


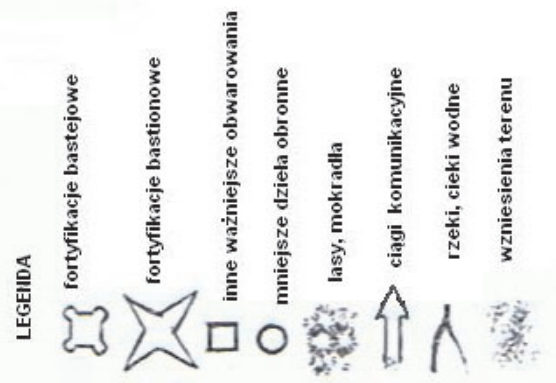

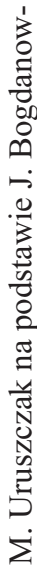
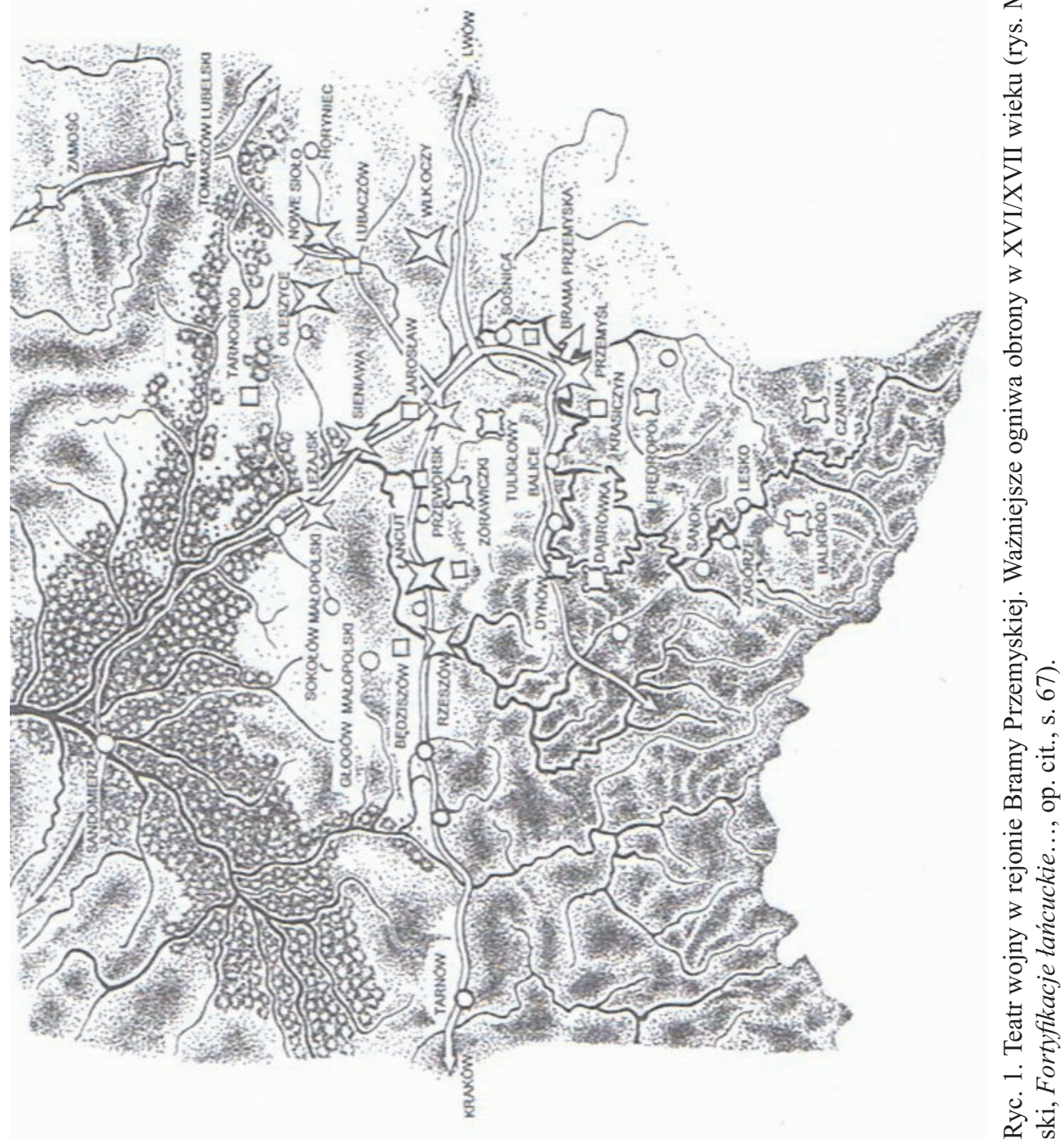
dodatkowo ułatwiały naturalne przeszkody w postaci lasów i mokradeł². Rozważna polityka osadnicza na terenach położonych na wschodnich rubieżach Rzeczypospolitej doprowadziła do wznoszenia miast-fortec (np. Zamość, Brody, Żółkiew, Stanisławów). Często podyktowane było to położeniem na skrzyżowaniu traktów handlowych (kupieckich). Przez wspomniany Zamość, na przykład, wiódł jeden szlak prowadzący ze Lwowa, przez Rawę Ruską, Łabunię, Krasnystaw i Lublin do Warszawy, oraz drugi, z Kijowa przez Uściług, Szczebrzeszyn, Zawichost do Krakowa i Pragi ${ }^{3}$.

Rycina 1 ukazuje warownię łańcucką na tle podobnych obiektów obronnych wyposażonych zarówno w basteje, bastiony jak też inne umocnienia, a położonych w obrębie aktualnych granic Polski.

Pierwsza wzmianka pisana o fortalitium łańcuckim pochodzi z 1512 r. Po najeździe Tatarów na pobliskie tereny obiektem zainteresował się król Zygmunt Stary, który na odnowę łańcuckiej warowni ofiarował część podatku czopowego Annie z Szamotuł ${ }^{4}$. Wzrastające zagrożenie granic południowowschodnich powodowało chęć posiadania jak najdoskonalszych możliwości obronnych. Sprowadzono na teren Małopolski licznych krajowych i zagranicznych inżynierów wojskowych, którzy zwłaszcza w drugiej połowie XVI w. wznosili coraz to nowocześniejsze fortalicja. Szczególne zaś nasilenie ich budowy nastąpiło na przełomie XVI/XVII w. ${ }^{5}$ Dotychczasowa niewielka armia, tak zwanej obrony potocznej, strzegąca wschodnich granic Rzeczypospolitej, stała się niewystarczająca. W zakresie budownictwa obronnego podstawą obrony biernej nie obejmowano miast, będących albo w fazie rozwoju, bądź ze słabymi warunkami materialnymi. Stworzenie odpowiednich obwarowań, w stanie ciągłego zagrożenia i spustoszeń, okazywało się niewykonalne. W tej sytuacji urządzenia obronne kształtowano niezwykle różnorodnie ${ }^{6}$. Sprawiać to może wrażenie, iż tylko na terenie południowo-wschodniej Polski powstawały w drugiej połowie XVII i XVIII w. założenia służące obronie. Nie jest to do końca zgodne z faktami, gdy prześledzimy historię rozmaitych budowli o podobnym przeznaczeniu w Polsce, jednakże ich zagęszczenie w tym właśnie regionie spowodowane było nasilonymi najazdami. Kolejno po sobie rozrastały się na tym obszarze zdobycze nowożytnej, europejskiej myśli fortyfikacyjnej takie, jak: budowle typu basztowo-bastejowego, warow-

\footnotetext{
${ }^{2}$ Idem, Problemy systematyki i konserwacji ziemnych dzieł obronnych od końca XVI do końca XIX wieku na terenie województwa rzeszowskiego, [w:] Opieka nad Zabytkami, Rzeszów 1967, s. 30 .

${ }^{3}$ W. Przegon, Zmiany użytkowania ziemi na przyktadzie miasta Podgórza i Zamościa (w świetle materiałów kartograficznych), Kraków, 2011, s. 40.

${ }^{4}$,Maiestas regia dedit duo quartalia exactionis czopowego Anne de Schamotuli de oppido ipsius dicto Lanczuth pro reformando ibidem fortalitio, ad eundem exactorem", cyt. za: Z. Szust, Średniowiecze Łańcuta, Łańcut 1957, s. 24-25.

${ }^{5}$ J. Bogdanowski, Fortyfikacje tańcuckie..., op. cit., s. 63.

${ }^{6}$ Ibidem, s. 62.
} 
ne, pięcioboczne dzieła obronne typu puntone, bastiony włoskie, jak również bastiony ziemne staro-i nowoholenderskie, nie wyłączając innych systemów ${ }^{7}$. Zdarzały się wprawdzie obiekty z pozoru tylko militarne, jak na przykład Mirów, z narysem bastionowym tarasu, służącym celom dekoracyjnym. Jednakże fortyfikacje zamków XVII-wiecznych, takich jak Wiśnicz, Rzeszów, Biała Podlaska czy przedmiotowy Łańcut, miały w pełni obronne znaczenie ${ }^{8}$.

Fortyfikacja otaczająca zamek łańcucki, inspirowana holenderską sztuką obronną, należała do szczytowych osiągnięć tego rodzaju budownictwa siedemnastowiecznej Polski. Zaprojektowana na planie gwiazdy pięcioramiennej, składała się z 5 bastionów połączonych krótkimi, prostymi odcinkami tzw. kurtynami. Na wysoko umieszczonym szańcu przewidziano około 80 dział do obrony zamku9 . Do naszych czasów, w niezmienionej postaci, przetrwała fosa widoczna na ryc. 3 , gdzie zaprezentowano wjazd na teren fortecy, poprzedzony dodatkowymi umocnieniami ziemnymi.

$\mathrm{Na}$ skuteczne wykorzystanie zarówno pojedynczych fortalicji, jak i całej ich sieci miały też wpływ dodatkowe czynniki. Często zły stan urządzeń militarnych, jak też brak współpracy między niezorganizowanymi i nieposiadającymi wzajemnego dowództwa obszarami utrudniało skuteczną obronę, szczególnie w starciach z Tatarami ${ }^{10}$. Obronę pogarszały dodatkowo konflikty między szlachtą, czego przykładem może być działalność słynnego „Łańcuckiego Diabła"11, czyli starosty zygwulskiego, Stanisława Stadnickiego, symbolu samowoli, zdrady, warcholstwa i pieniactwa w ówczesnej Polsce. Żywot wypełniały mu gwałty, rozboje, przywłaszczanie przywilejów, a nawet bicie własnej monety, przy jednoczesnym lekceważeniu wyroków królewskich ${ }^{12}$.

Nieustanne zagrożenie i powtarzające się najazdy w tym właśnie okresie, czyli w czasach gdy polska sztuka wojenna osiągnęła najwyższy poziom, spowodowały, iż ogólnym dążeniem stawało się rozstrzyganie wojny w polu. Dawało to bowiem pełne możliwości wykorzystania taktycznej przewagi nad przeciwnikiem $^{13}$. Rozwijała się też cała sieć drobnych fortalicji szlacheckich. W przypadkach zaś bezpośredniego zagrożenia wzmacniano urządzenia obronne miast, a nawet prowadzono budowę umocnień wsi ${ }^{14}$. W działaniach wojennych dominowała strategiczna mobilność i na tym tle spora inwencja powiązana z warunkami lokalnymi. Ogromny obszar wojennego teatru usuwał

${ }^{7}$ L. Kajzer, Zamki i spoteczeństwo, Łódź 1993, s. 248.

${ }^{8}$ J. Zachwatowicz, Architektura Polska do połowy XIX wieku, Warszawa, 1956, s. 22-23.

${ }^{9}$ J. Żurawski, Z. Postępski, Łańcut, Warszawa, 1975, s. 7.

${ }^{10}$ J. Sikorski, Zarys dziejów wojskowości polskiej do roku 1864, Warszawa, 1965, t. I, s. 304-305 .

${ }^{11}$ W. Łoziński, Prawem i lewem, Kraków 1966, t. II.

12 J. Żurawski, Z. Postępski, Łańcut..., op. cit, s. 6.

${ }^{13}$ J. Sikorski, Zarys dziejów wojskowości polskiej..., op. cit., s. 386.

${ }^{14}$ F. Kotula, Warownie chtopskie w XVII wieku w ziemi przemyskiej i sanockiej, [w:] Studia i materiaty do historii wojskowości 1962, t. VIII, cz. 1. 
na plan dalszy konieczność prowadzenia uporczywej, długotrwałej wojny wokół pojedynczego dzieła. Obwarowaniom przypadła rola stanowienia baz do przemieszczanych operacji wojennych, chroniąca przed zaskoczeniem, dzięki wspomnianej ruchliwości. Dzieła sztuki obronnej, zamki, miasta i klasztory warowne rozmieszczano nieregularnie, przede wszystkim osłaniając główne szlaki $^{15}$.

Historycy zauważają z uznaniem, iż polska sztuka wojenna w XVII w. przeżywała okres rozkwitu i świetności na europejską skalę ${ }^{16}$. Jeżeli zatem słuszne byłoby nazwanie ówczesnej Polski przedmurzem w walce z Tatarami i Turkami, to wschodnia część Małopolski i dalej na wschód położone ziemie spełniały rolę głównego stanowiska obrony.

Obronność zespołu dworskiego była cechą bardzo pożądaną, o czym informowały liczne XVI-XVII-wieczne opisy zawarte w księgach sądowych, ze szczególnym nasileniem południowo-wschodnich ziem Rzeczypospolitej. Każdy niemal dom szlachecki w tym obszarze posiadał umocnienia takie jak wał czy przeszkody wodne ${ }^{17}$. Obiekty takie były uzupełnieniem dla silniejszych twierdz, będących niejako szkieletem obrony. W dużej liczbie były w stanie odeprzeć nawet silnego przeciwnika ${ }^{18}$.

Jednocześnie wprowadzane były najnowsze rozwiązania militarne w obiektach możnowładców. W Małopolsce powstał szereg zamków prywatnych, o wzmocnieniach bastionowych, stanowiących system obrony według coraz to nowszych wzorów. Na planie pięciobocznym (pentagonalnym) zostały założone obwałowania zamków w Wiśniczu, w omawianym Łańcucie, czy w położonym dalej zamku Krzyżtopór w Ujeździe. Rodziło to szereg problemów związanych z korzystaniem z przestrzeni mieszkalnych w takim budynku. Łańcut, podobnie jak Wiśnicz, posiadał rezydencję wolnostojącą, podczas gdy w zamku ujazdowskim, połączona była ona z systemem fortyfikacyjnym. Jednocześnie warto zauważyć, iż ten typ umocnień, określany mianem palazzo in fortezza ${ }^{19}$, stawał się częstym wzorem do naśladowania dla mniej zamożnych przedstawicieli szlachty ${ }^{20}$. W Łańcucie wprowadzano z biegiem lat stopniowe modernizacje. Kamiennym płaszczem umocniono stok fosy. Dodano linię strzelnic dla broni ręcznej na skraju fosy przed wałem, oraz na grobli przed mostem ${ }^{21}$.

${ }^{15}$ J. Bogdanowski, Fortyfikacje tańcuckie..., op. cit., s. 65.

${ }^{16}$ L. Kajzer, Zamki i spoleczeństwo, Łódź 1993, s. 247.

${ }^{17}$ Ibidem, s. 208.

${ }^{18}$ J. Bogdanowski, Problemy systematyki i konserwacji ziemnych dziet obronnych..., op. cit., s. 31 .

${ }^{19}$ B. Guerquin, Zamki w Polsce, Warszawa, 1974, s. 69.

${ }^{20}$ L. Kajzer, S. Kołodziejski, J. Salm, Leksykon zamków w Polsce, Warszawa 2004, s. 73.

${ }^{21}$ E. Baniukiewicz, Z. Wiśniewska, Zamek w Łańcucie, Warszawa 1970, s. 7. 


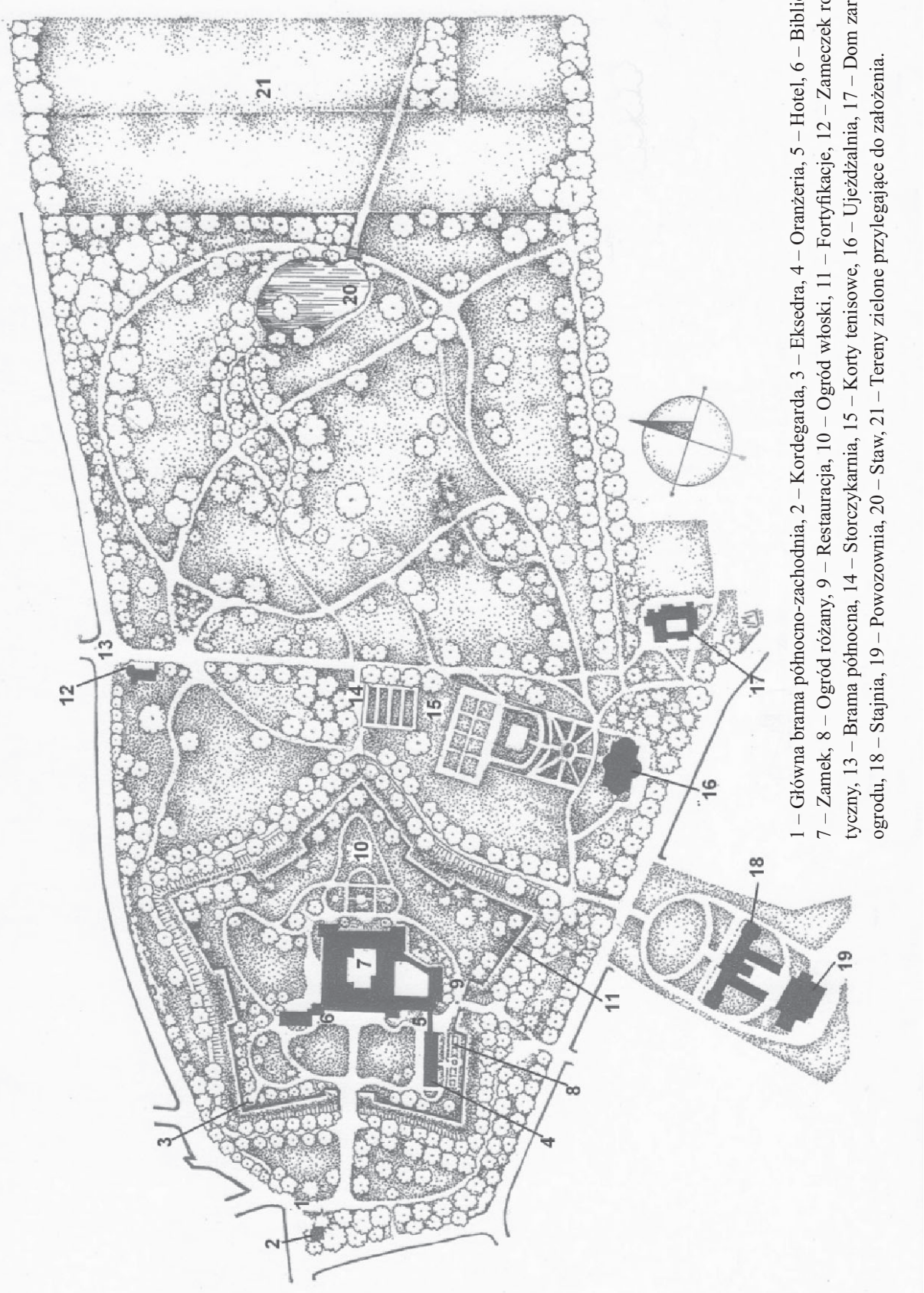

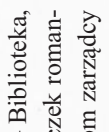

6 ๑

1
1

의 응

营

눙

$+$

括

落

? $\overrightarrow{0}, 0$

in

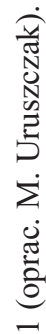

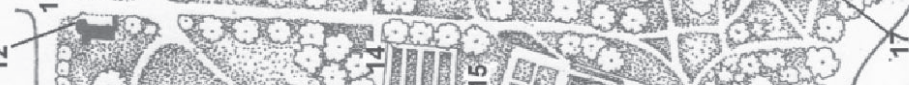

당

긍

릉

3

壱

$\frac{0}{0}$

氕 
II. Elementy fortyfikacyjne w kompozycji parkowej rezydencji Lańcut jako świadectwo roli obiektu w XVI/XVII wieku. Założenia obronne Łańcuta są w pełni widoczne w dzisiejszym parku otaczającym pałac. Fortyfikacyjne elementy takie jak fosa, będąca pozostałością założenia obronnego z XVII w., sto lat później wykorzystano jako romantyczny, „rycerski” akcent założenia parkowego. Wprowadzono jednocześnie barokową aleję, otaczającą dawny obwód obronny (ryc. 2$)^{22}$.

Park w stanie obecnym datowany jest w swej całościowej formie na przełom XIX i XX w., przy jednoczesnej obecności elementów pochodzących nawet z wieku XVII. Stylistyka natomiast została sklasyfikowana jako kaligraficzno-naturalistyczna, z zastrzeżeniem złożoności założenia ${ }^{23}$. Od wieku XVIII widoczny był rozwój parku łańcuckiego. Powstały wówczas wspomniane alejowe układy, łączące ciasny obręb zamku z rozległym krajobrazem $^{24}$, zaś niewielki ogród letni rozbudowano następnie do kilkunastu niejako osobnych wnętrz ${ }^{25}$.

Wielkie zasługi w przebudowaniu zamku łańcuckiego poniosła księżna Izabela Elżbieta Czartoryska, żona dziedzica dóbr łańcuckich, marszałka koronnego Stanisława Lubomirskiego ${ }^{26}$. Izabela z Czartoryskich Lubomirska żyła w latach 1733-1816. Brała czynny udział w wydarzeniach politycznych kraju, stając się jednocześnie po śmierci męża, marszałka Czartoryskiego, wyłączną właścicielką fortuny, składającej się 360 wsi, 15 miast, kilku zamków i pałaców. Olbrzymie dochody pozwalały jej wznosić od podstaw i przebudowywać rezydencje, gromadzić dzieła sztuki. Jej działalność jako mecenasa sztuki była nierzadko prekursorska. Cechował ją celny dobór wykonawców reprezentujących aktualne i modne kierunki w sztuce.

Księżna przeistoczyła zamek w olśniewającą rezydencję pałacową epoki oświecenia. Zatrudniała przy tym wybitnych artystów, takich jak Vincenzo Brema, Jan Chrystian Kamzetzer czy Szymon Bogumił Zug, którzy byli rzeczywistymi twórcami architektury obiektu (ryc. 3$)^{27}$.

Park w różnych epokach sztuki ogrodowej wzbogacał się o nowe wzory. W dobie dominacji arkadyjskiej stylizacji ogrodów, samotniki, klomby i wszelkie artefakty ogrodowe zaczęły nabierać szlachetnych proporcji, w udanych zestawieniach $\mathrm{z}$ wielkością wnętrz i tłem ścian. Harmonię kompozycji widać szczególnie, gdy patrzymy na stojącą przed pałacem eksedrę, wzorowy przykład na skalę kraju ${ }^{28}$. Był to otwarty element architektoniczny

${ }^{22}$ J. Żurawski, Z. Postępski, Łańcut..., op. cit., s. 15.

${ }^{23}$ J. Bogdanowski, Polskie ogrody ozdobne, Warszawa 2000, s. 317.

${ }^{24}$ Ibidem, s. 86.

${ }^{25}$ Ibidem, s. 84.

${ }^{26}$ Polski Słownik Biograficzny, Tom XVII. Wrocław-Warszawa-Kraków-Gdańsk, 1972, s. 625-629.

${ }^{27}$ J. Żurawski, Z. Postępski Łańcut ..., op. cit., s. 9.

${ }^{28}$ J. Bogdanowski, Polskie ogrody ozdobne..., op. cit., s. 124. 


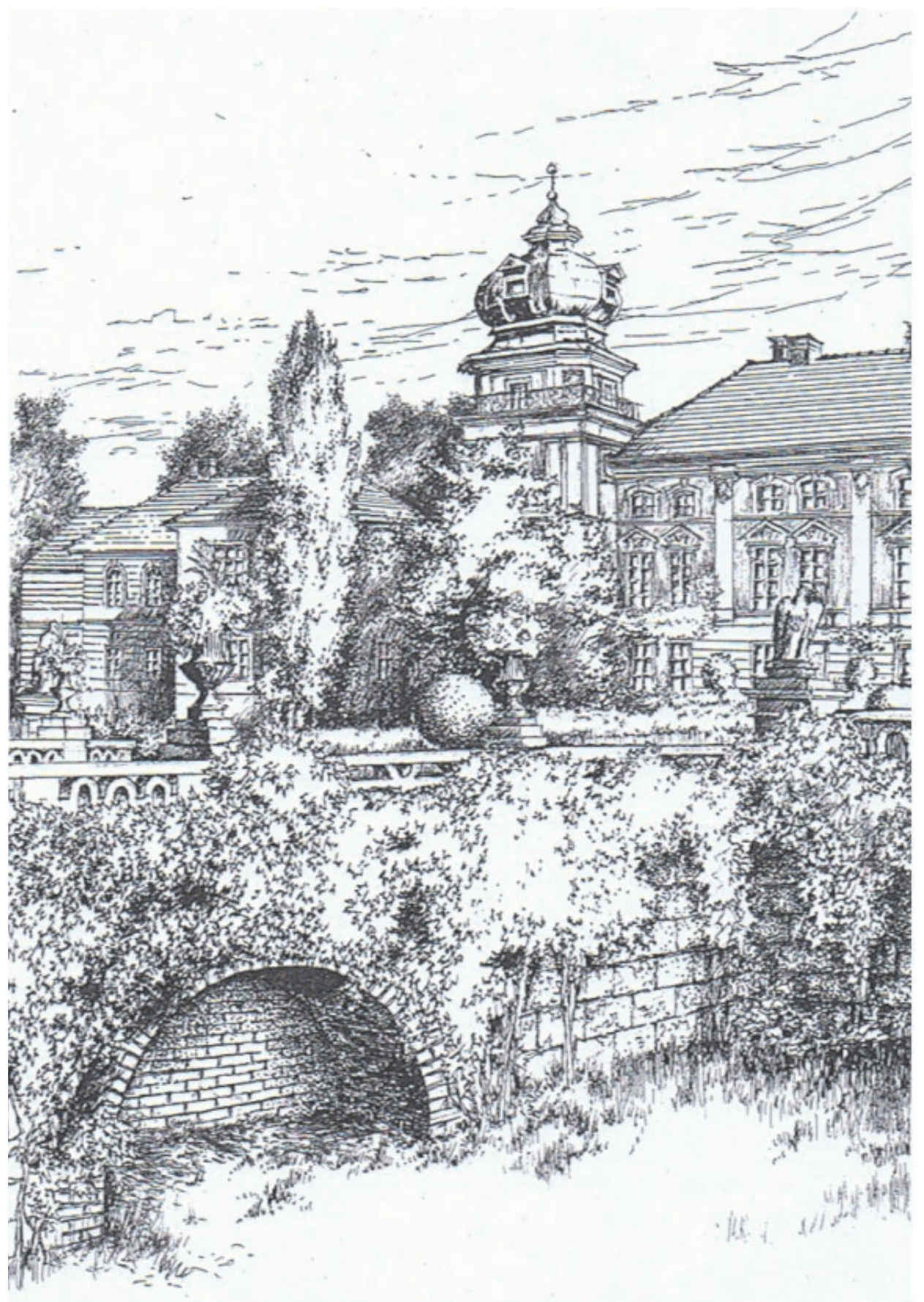

Ryc. 3. Zamek w Łańcucie. Widok fortyfikacji bastionowych na tle zamku od strony zachodniej (rys. M. Uruszczak). 
w postaci półkolistej kolumnady, służącej zaakcentowaniu posągu umieszczonego wewnątrz przestrzeni półkola ${ }^{29}$.

Warto zauważyć, iż w epoce popularności parków naturalistycznych, oprócz powstałych w Łańcucie ,gąszczy”, polan, mających podobnie jak zagajniki możliwie dokładnie naśladować naturę, wprowadzano też najnowsze trendy w sztuce ogrodowej, choćby projektując pnącza na elewacji pałacu ${ }^{30}$.

Mimo tragedii narodowej rozbiorów, wojen, przemarszów zaborczych wojsk i wszystkich związanych z tym zniszczeń, sztuka ogrodowa, jako nieodłączny atrybut magnackiej rezydencji i szlacheckiego dworu, trwała i rozwijała się ${ }^{31}$. Z drugiej strony przemiany, jakie następowały w otoczeniu miast i wsi, w drugiej połowie XIX w., pod wpływem uprzemysłowienia, otwierały w sztuce ogrodowej tendencje do tworzenia niejako modeli krajobrazów stopniowo przemijających. Na tym właśnie tle w Łańcucie scalono przeciwstawne formy. W jednej, doprowadzonej do kaligraficznej perfekcji kompozycji połączono park zamkowy, zachowując jego autonomiczną geometryczność, wprowadzając stopniowo spacerowicza w rozległy krajobraz ${ }^{32}$. Zadziwia zresztą do dziś ta umiejętność osiągania harmonii przez równowagę doboru elementów ${ }^{33}$.

Patrząc na rzut założenia rezydencjonalno-ogrodowego w Łańcucie, dostrzec można zarówno bogactwo historycznego dorobku sztuki militarnej, jak też potencjał wyobraźni artystycznej tworzących ogród architektów i architektów krajobrazu. Płynne linie wschodnich partii ogrodu w umiejętny sposób splatają się z prostokreślnymi drogami obwodowymi. Łańcut słynie W równym stopniu ze swojego muzeum pałacowego, jak i uzupełniających ogród „atrakcji”, takich jak powozownia, storczykarnia, bażanciarnia. Były one do założenia wprowadzane stopniowo w ciągu stuleci przy jednoczesnym uwzględnianiu wygody użytkowania jak i subtelności tworzonych wnętrz parkowych. Wszystkie te elementy składają się na barwny obraz dawnych obyczajów arystokratycznych, zmienności mody i upodobań. Są śladem pozycji społecznej i politycznej właścicieli w minionych wiekach naszej historii ${ }^{34}$.

\footnotetext{
${ }^{29}$ M. Siewniak, A. Mitkowska, Tezaurus sztuki ogrodowej, Warszawa 1998, s. 70.

${ }^{30}$ Ibidem, s. 156.

${ }^{31}$ G. Ciołek, Polskie ogrody ozdobne, Warszawa 1978, s. 134.

${ }^{32} \mathrm{~J}$. Bogdanowski, Polskie ogrody ozdobne, op. cit., s. 163.

${ }^{33}$ Ibidem, s. 168.

${ }^{34}$ J. Żurawski, Z. Postępski, Łańcut..., op. cit, s. 13-15.
} 